\section{CIRM's expanding reach}

\section{By Tim Fulmer, Senior Writer}

The California Institute for Regenerative Medicine's newest batch of grants differs from previous stem cell research awards in two key ways-they are later stage and reflect CIRM's collaboration with agencies outside of California.

CIRM has awarded about $\$ 1$ billion to support a total of 321 grants since it was founded in November 2004. But the most recent set of awards-a total of $\$ 229.8$ million to 14 teams-is the first expected to result in IND submissions when work under the four-year grants is completed.

Canada's Cancer Stem Cell Consortium (CSCC) and the U.K.'s Medical Research Council (MRC) will provide an additional $\$ 35$ million and \$8 million, respectively, to fund portions of research carried out in labs located in those countries.

Unlike the Early Translational Research grants that CIRM issued in April, the latest round is highly disease oriented, with each research proposal focused on a single area such as cancer, HIV, type 1 diabetes, macular degeneration and stroke (see Table 1, “CIRM grants”).

Only two biotech companies received grants: Novocell Inc. and Calimmune Inc. CIRM spokesperson Don Gibbons did not disclose if other biotechs applied for funding and were turned down or if this round of applicants was dominated by university researchers simply by chance. Nor did he disclose how the institute determined the amount of funding extended to the companies.

A \$20 million grant to a Novocell-led group will support the development of encapsulated insulin-producing cells derived from human embryonic stem cells (hESCs) to treat type 1 diabetes.

Novocell SVP and CSO Emmanuel Baetge told SciBX that encapsulating the insulin-producing cells in a semipermeable polyethylene glycol (PEG)-based coating ensures ample transport of nutrients and oxygen into the cells while protecting them from a potential host immune response and thus reducing the need for long-term immunosuppression. Moreover, the cells will be implanted subcutaneously to allow for monitoring and retrieval if necessary.

In nonhuman primates, Novocell has shown that encapsulated islet cells derived from same-species donors required immunosuppression for 30 days following implantation, after which the islets functioned for 20 months without the need for additional immunosuppression.

Meanwhile, Novocell has developed a method to generate functional islets from hESCs. Last year, company researchers reported

Table 1. CIRM grants. Below is a list of 14 research grants awarded by the California Institute for Regenerative Medicine (CIRM) to develop stem cell-based therapies.

\begin{tabular}{|c|c|c|c|}
\hline Lead institution & $\begin{array}{l}\text { Lead principal } \\
\text { investigator }\end{array}$ & $\begin{array}{c}\text { CIRM } \\
\text { funding (\$M) }\end{array}$ & Proposal summary \\
\hline Cedars-Sinai Medical Center & Eduardo Marbán & 5.6 & Repair heart tissue damaged by heart attack using autologous heart stem cells \\
\hline City of Hope & Karen Aboody & 18.0 & Treat brain tumors using neural stem cells modified to carry a tumor-killing drug \\
\hline City of Hope & John Zaia & 14.6 & $\begin{array}{l}\text { Treat HIV using genetically modified autologous hematopoietic stem cells that give } \\
\text { rise to HIV-resistant T cells }\end{array}$ \\
\hline Novocell Inc. & Emmanuel Baetge & 20.0 & $\begin{array}{l}\text { Treat type } 1 \text { diabetes by implanting islet cells generated from human embryonic } \\
\text { stem cells (hESCs) }\end{array}$ \\
\hline Salk Institute for Biological Studies & Samuel Pfaff & 15.6 & $\begin{array}{l}\text { Treat amyotrophic lateral sclerosis (ALS) by implanting precursor astrocyte cells } \\
\text { derived from hESCs }\end{array}$ \\
\hline Stanford University & Alfred Lane & 11.7 & $\begin{array}{l}\text { Treat epidermolysis bullosa using genetically modified induced pluripotent stem cells } \\
\text { derived from the patient's skin cells }\end{array}$ \\
\hline Stanford & Gary Steinberg & 20.0 & Treat stroke using implanted neural stem cells derived from hESCs \\
\hline Stanford & Irving Weissman & 20.0 & Develop a mAb that targets leukemia stem cells \\
\hline $\begin{array}{l}\text { University of California, Los Angeles } \\
\text { (UCLA) }\end{array}$ & Irvin $\mathrm{Chen}^{\mathrm{A}}$ & 20.0 & $\begin{array}{l}\text { Treat HIV using RNAi-modified autologous hematopoietic stem cells that give rise } \\
\text { to HIV-resistant T cells }\end{array}$ \\
\hline UCLA & Donald Kohn & 9.2 & $\begin{array}{l}\text { Treat sickle cell disease using genetically modified hematopoietic stem cells that } \\
\text { become normal red blood cells }\end{array}$ \\
\hline UCLA & Dennis Slamon & 20.0 & Develop compounds that target cancer stem cells in solid tumors \\
\hline University of California, San Diego & Dennis Carson & 20.0 & Develop mAbs and small molecules that destroy leukemia stem cells \\
\hline University of California, San Francisco & Mitchel Berger & 19.2 & Treat brain tumors using neural stem cells modified to carry a tumor-killing drug \\
\hline University of Southern California & Mark Humayun & 15.9 & Treat macular degeneration using transplanted retinal cells derived from hESCs \\
\hline Total & & 229.8 & \\
\hline
\end{tabular}




\section{PUBLIC-PRIVATE INTERFACE}

that pancreatic endoderm derived from hESCs generated glucoseresponsive, insulin-secreting cells in mice. ${ }^{1}$

The next step is to encapsulate those hESC-derived islet cells.

Baetge told SciBX that the company's approach potentially solves a key difficulty facing all encapsulation technologies: balancing accessibility to serum nutrients with the need for disguise from the host immune system.

The coating's semipermeability ensures glucose and insulin can freely diffuse into and out of the islets, whereas the PEG molecules provide a biocompatible barrier that prevents the islets from contacting host immune cells and triggering an immune response, he said.

Calimmune and the University of California, Los Angeles (UCLA) received a \$20 million grant to develop RNAi-modified hematopoietic stem cells that differentiate into HIV-resistant T cells.

Irvin Chen, co-principal investigator on the grant, told SciBX that his lab and the biotech will split research responsibilities. Calimmune will shoulder late preclinical development, including "clinical assay development and validation, therapeutic gene vector production and management of regulatory issues," he said. Chen is professor of microbiology and immunology at UCLA and director of the UCLA AIDS Institute.

In 2007, Chen and colleagues at UCLA, the California Institute of Technology and NIH's National Heart, Lung, and Blood Institute reported that RNAi-based stem cell transplants developed into lymphocytes.
The lymphocytes were less susceptible to infection in nonhuman primate models of HIV than lymphocytes not expressing the RNAi. ${ }^{2}$

Next year, CIRM expects to award two sets of grants supporting early preclinical research, Gibbons told SciBX.

"One of those sets will focus on basic stem cell biology and will include some funding from Japanese sources to support researchers in that country," he said. "A second set of grants, which will focus on immunology and stem cells, will involve Australian researchers and include funding from Australian sources."

Fulmer, T. SciBX 2(44); doi:10.1038/scibx.2009.1621

Published online Nov. 12, 2009

\section{REFERENCES}

1. Kroon, E. et al. Nat. Biotechnol. 26, 443-452 (2008)

2. An, D.S. et al. Proc. Natl. Acad. Sci. USA 104, 13110-13115 (2007)

\section{COMPANIES AND INSTITUTIONS MENTIONED}

California Institute for Regenerative Medicine, San Francisco, Calif. California Institute of Technology, Pasadena, Calif.

Cancer Stem Cell Consortium, Toronto, Ontario, Canada

Calimmune Inc., Tucson, Ariz.

Medical Research Council, London, U.K.

National Heart, Lung, and Blood Institute, Rockville, Md.

National Institutes of Health, Bethesda, Md.

Novocell Inc., San Diego, Calif.

University of California, Los Angeles, Calif. 